\title{
Subtype-specific therapy for autoimmune neuropathies?
}

\section{OPEN}

Eric Lancaster, $\mathrm{MD}, \mathrm{PhD}$

Steven S. Scherer, MD,

$\mathrm{PhD}$

Correspondence to

Dr. Lancaster:

eric.lancaster@uphs.upenn.edu

Neurol Neuroimmunol

Neuroinflamm

2015;2:e152; doi: 10.1212/

NXI.0000000000000152
Guillain-Barré syndrome (GBS) and chronic inflammatory demyelinating polyneuropathy (CIDP) are the most common autoimmune neuropathies. In both disorders, different variants have been described, reflecting the types of axons that are affected (motor and/or sensory), the nature of the injury (axonal vs demyelinating), and the response to treatment. Because most patients respond to therapies that target autoantibodies (plasmapheresis and IV immunoglobulin [IVIg]), these disorders are thought to be antibody-mediated. Consistent with this, autoantibodies to different peripheral nerve glycolipids, especially complexes of multiple gangliosides, are found in specific subtypes of patients. ${ }^{1}$ Moreover, high titers of antibodies against GM1 and GQ1b gangliosides are highly associated with multifocal motor neuropathy ${ }^{2}$ and Miller Fisher syndrome/Bickerstaff encephalitis, ${ }^{3}$ respectively. There is strong evidence from both human and animal models that the binding of autoantibodies to their cognate lipid antigens fixes complement that in turn damages myelinated motor and/ or sensory axons.

More recently, autoantibodies to protein antigensneurofascins (axonal NF186 and glial NF155), gliomedin, and contactin - have been described in a small proportion of patients with GBS and/or CIDP., 4,5 These are cell adhesion molecules important for glialaxonal interactions at nodes (NF186 and gliomedin) and paranodes (contactin-1 and NF155). Patient antibodies target surface epitopes in their large extracellular domains and are plausibly directly pathogenic, but what is the evidence?

In animal models, autoantibodies against these proteins are sufficient to cause neuropathy. In the case of gliomedin, an active immunization produces acute peripheral neuropathy, and transfer of the antibodies to other animals can worsen autoimmune neuropathy. ${ }^{6}$ In the case of NF186, active immunization did not cause neuropathy in 1 animal model, ${ }^{6}$ but injecting 2 pan-neurofascin monoclonal antibodies worsened experimental neuritis in a different animal model. ${ }^{5}$
The data from humans are more circumstantial. Querol et al.7 previously found IgG4 autoantibodies to NF155 in 4 patients with CIDP who were unresponsive to IVIg (but some responded partially to plasmapheresis) and often had pronounced tremor. In the current issue of Neurology ${ }^{\circledR}$ Neuroimmunology \& Neuroinflammation, Querol et al. ${ }^{8}$ expand on this finding by examining the clinical effects of rituximab in 2 of the patients with IgG4 antibodies against NF155 as well as another patient with IgG4 antibodies against contactin-1 (who also had aggressive motor CIDP and a poor response to immune therapy). Rituximab substantially lowered $\operatorname{IgG} 4$ titers against NF155 or contactin-1 in all 3 patients. The 2 patients (1 with IgG4 antibodies against NF155 and 1 with IgG4 antibodies against contactin-1) who had dramatic clinical responses to rituximab had been affected for less than a year. The authors note that the 1 patient who responded minimally had had CIDP for 15 years, so axonal loss may have precluded recovery.

IgG4 has several distinct features that pertain to the current study (for an excellent review see reference 9).

1. IgG4 does not effectively cross-link target antigens or fix complement, both of which mediate other autoimmune diseases.

2. Direct functional effects of IgG4 on target proteins are plausible. Thus, autoantibodies to contactin1 bind to specific surface epitopes on contactin1 and prevent contactin-1 from interacting with NF155. ${ }^{10}$ Conversely, it is possible that antibodies to NF155 block the interaction between NF155 and contactin-1, a finding that might help us understand the similarities of the 2 phenotypes.

3. B cell depletion with rituximab is remarkably effective in many IgG4-mediated diseases (including anti-muscle-specific tyrosine kinase myasthenia gravis [MUSK]).

The previous antibody studies therefore lead to the recognition of a particular subset of patients with

See article

From the Department of Neurology, The Perelman School of Medicine, The University of Pennsylvania, Philadelphia.

Funding information and disclosures are provided at the end of the editorial. Go to Neurology.org/nn for full disclosure forms.

This is an open access article distributed under the terms of the Creative Commons Attribution-NonCommercial-NoDerivatives License 4.0 (CC BY-NC-ND), which permits downloading and sharing the work provided it is properly cited. The work cannot be changed in any way or used commercially. 
refractory CIDP and also suggested a rational treatment strategy. The current study provides additional motivation to study rituximab treatment for CIDP associated with IgG4 antibodies to nerve proteins.

Although the study by Querol et al. ${ }^{8}$ should be considered preliminary, the possibility of an additional effective therapy for some patients with CIDP is welcome news for patients and clinicians. In the short term, we should be able to determine whether IgG4 antibodies mediate some forms of CIDP and whether rituximab is better than current conventional treatments. The work also motivates efforts to identify more autoantibodies associated with autoimmune neuropathy. These may lead to a better understanding of the pathogenesis of CIDP, increasingly useful panels of diagnostic tests, and individualized therapy for every patient with autoimmune neuropathy.

\section{AUTHOR CONTRIBUTIONS}

Eric Lancaster: drafting/revising the manuscript, analysis or interpretation of data. Steven S. Scherer: drafting/revising the manuscript.

\section{STUDY FUNDING}

No targeted funding reported.

\section{DISCLOSURE}

E. Lancaster received honoraria from Grifols Inc; has consulted for Medimmune Inc; received fees for expert review of cases from Federal Vaccine Injury Compensation Program; and received research support from National Institute of Neurological Disorders and Stroke and Dana Foundation. S.S. Scherer is on the scientific advisory board for Charcot-MarieTooth Association; is on the editorial board for ASN Neuro, Cell and Tissue Research, Experimental Neurology, Glia, Journal of Neuroscience Research, Journal of the Peripheral Nervous System, Journal of Clinical Investigation, Neuron Glia Biology, Journal of Neuroscience, and Journal of the Neurological Sciences; has consulted for CMT Association; and received research support from NIH/NINDS and Muscular Dystrophy Association. Go to Neurology.org/nn for full disclosure forms.

\section{REFERENCES}

1. Rinaldi S, Brennan KM, Kalna G, et al. Antibodies to heteromeric glycolipid complexes in Guillain-Barre syndrome. PLoS One 2013;8:e82337.

2. Galban-Horcajo F, Fitzpatrick AM, Hutton AJ, et al. Antibodies to heteromeric glycolipid complexes in multifocal motor neuropathy. Eur J Neurol 2013;20:62-70.

3. Shahrizaila N, Yuki N. Bickerstaff brainstem encephalitis and Fisher syndrome: anti-GQ1b antibody syndrome. J Neurol Neurosurg Psychiatry 2013;84:576-583.

4. Devaux JJ, Odaka M, Yuki N. Nodal proteins are target antigens in Guillain-Barre syndrome. J Peripher Nerv Syst 2012;17:62-71.

5. $\mathrm{Ng} \mathrm{JK}$, Malotka J, Kawakami N, et al. Neurofascin as a target for autoantibodies in peripheral neuropathies. Neurology 2012;79:2241-2248.

6. Devaux JJ. Antibodies to gliomedin cause peripheral demyelinating neuropathy and the dismantling of the nodes of Ranvier. Am J Pathol 2012;181:1402-1413.

7. Querol L, Nogales-Gadea G, Rojas-Garcia R, et al. Neurofascin IgG4 antibodies in CIDP associate with disabling tremor and poor response to IVIg. Neurology 2014;82: 879-886.

8. Querol L, Rojas-García R, Diaz-Manera J, et al. Rituximab in treatment-resistant CIDP with antibodies against paranodal proteins. Neurol Neuroimmunol Neuroinflamm 2015;2:e149; doi: 10.1212/NXI.0000000000000149.

9. Huijbers MG, Querol LA, Niks EH, et al. The expanding field of IgG4-mediated neurological autoimmune disorders. Eur J Neurol 2015;22:1151-1161.

10. Labasque M, Hivert B, Nogales-Gadea G, Querol L, Illa I, Faivre-Sarrailh C. Specific contactin N-glycans are implicated in neurofascin binding and autoimmune targeting in peripheral neuropathies. J Biol Chem 2014;289: 7907-7918. 


\title{
Neurology \\ Neuroimmunology \& Neuroinflammation
}

\author{
Subtype-specific therapy for autoimmune neuropathies? \\ Eric Lancaster and Steven S. Scherer \\ Neurol Neuroimmunol Neuroinflamm 2015;2; \\ DOI 10.1212/NXI.0000000000000152
}

This information is current as of September 24, 2015

\section{Updated Information \& Services}

References

Subspecialty Collections

Permissions \& Licensing

Reprints including high resolution figures, can be found at:

http://nn.neurology.org/content/2/5/e152.full.html

This article cites 10 articles, 2 of which you can access for free at: http://nn.neurology.org/content/2/5/e152.full.html\#\#ref-list-1

This article, along with others on similar topics, appears in the following collection(s):

Autoimmune diseases

http://nn.neurology.org//cgi/collection/autoimmune_diseases

Chronic inflammatory demyelinating polyneuropathy

http://nn.neurology.org//cgi/collection/chronic_inflammatory_demyeli nating_polyneuropathy

Information about reproducing this article in parts (figures,tables) or in its entirety can be found online at:

http://nn.neurology.org/misc/about.xhtml\#permissions

Information about ordering reprints can be found online: http://nn.neurology.org/misc/addir.xhtml\#reprintsus

Neurol Neuroimmunol Neuroinflamm is an official journal of the American Academy of Neurology.

Published since April 2014, it is an open-access, online-only, continuous publication journal. Copyright $(\subset$ 2015 American Academy of Neurology. All rights reserved. Online ISSN: 2332-7812.

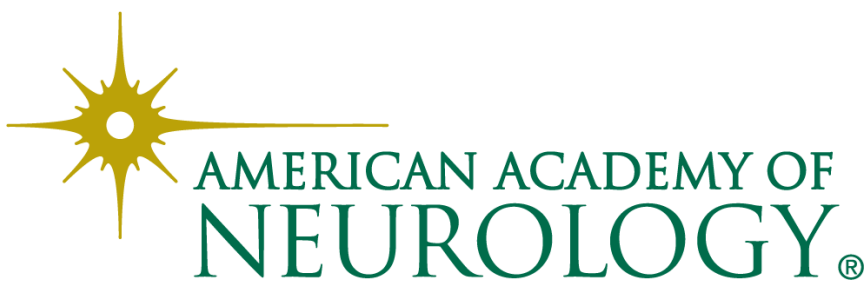

